\title{
KORONACJA NOWEGO OBRAZU MATKI BOSKIEJ SZKAPLERZNEJ W BERDYCZOWIE NA UKRAINIE
}

\author{
W P ROW A D Z N IE
}

Po 65 latach nieobecności karmelici bosi ponownie objęli 15 XI $1991 \mathrm{r}$. w posiadanie sławne niegdyś sanktuarium Matki Boskiej Berdyczowskiej. $\mathrm{Z}$ wielkim trudem, ale i zapałem, podjęli pracę misyjną duszpasterstwa parafialnego i sanktuaryjnego. Wpierw przeprowadzili rekonstrukcje i rewaloryzacje dolnego kościoła, zamienionego na sale gimnastyczną. Przystosowali go do religijnego kultu. Górny kościół - właściwe sanktuarium Matki Bożej - jest całkowicie wypalony i potrzebuje pełnej rekonstrukcji wnętrza, począwszy od założenia nowych tynków, sztukaterii, posadzki i uposażenia, koniecznego do religijnego kultu. Podjęte prace trwać będą kilka lat. Uzależnione są od zdobycia na ten cel potrzebnych funduszy.

Jednakże najważniejszym zadaniem jest ewangelizacja - troska o dusze ludzkie - żywe świątynie Boga w Trójcy Jedynego. Ta misja jest najważniejsza sztuką - ,ars artium regimen animarum"! Stąd od samego początku (15 XI 1991) wśród rumowiska, straszących murów światyni, rozpoczęto składać Bogu eucharystyczną ofiarę, głosić Słowo Boże i udzielać sakramentów ludziom głodnym Słowa Bożego i samego Boga. Miejscowi parafianie w czynie społecznym uprzątnęli z otoczenia kościoła sterty gruzu i śmieci. Zdemontowali urządzenia sali gimnastycznej. Zrobili ławki i stół na ołtarz. Udekorowali świątynię. Biskup żytomierski Jan Purwiński 8 XII 1991 r. poświęcił obie świątynie i odprawił sumę odpustową ku radości i wzruszeniu wiernych, wypełniających wnętrze obu kościołów. I tak po 65. latach walki z religią wznowiona została działalność duszpasterska w sanktuarium Matki Bożej Berdyczowskiej.

Wieść o otwarciu sanktuarium w Berdyczowie, niegdyś duchowej stolicy Ukrainy, Wołynia i Podola, dotarła szybko do wszystkich dzielnic niepodległej Ukrainy. Wznowiony został spontaniczny ruch pielgrzymkowy na uroczystość Matki Boskiej Szkaplerznej (16 VII). Na liczne prośby duchowieństwa i wiernych o koronację nowego obrazu dla sanktuarium podjęte zostały starania o tę łaskę w Rzymie. Po przygotowaniu i złożeniu pełnej dokumentacji, zgodnie z przepisami Kościoła, Kongregacja Kultu Bożego i Dyscypliny Sakramentów, dekretem 
z dnia 10 III 1997 r. Prot. 339/97/L, zezwoliła na koronację obrazu Matki Bożej w Berdyczowie. Ojciec Święty Jan Paweł II, zatwierdzając pozytywną decyzję Kongregacji (pod tą sama data), zezwolił, na mocy wydanego brewe pod pieczęcią Rybaka, aby ta koronacja dokonała się jego powaga i w jego imieniu, dla większego rozwoju kultu Matki Bożej i duchowego dobra wiernych. Nowy obraz Matki Bożej Berdyczowskiej namalowany przez artystkę Bożenę Sowińska, został uroczyście poświęcony przez papieża Jana Pawła II, w kościele św. Jadwigi Królowej na osiedlu Azory w Krakowie, w dniu 9 VI 1997 r., w obecności delegacji z karmelitańskiej parafii w Berdyczowie. W uroczystość odpustową Matki Boskiej Szkaplerznej 20 VII tegoż roku nowy obraz uroczyście został intronizowany w berdyczowskim sanktuarium przez ks. bpa Jana Purwińskiego, który ogłosił wiernym jego koronację w dniu 19 VII 1998 r. Obecnie trwają przygotowania do tej uroczystości. W programie tego przygotowania należy przypomnieć genezę i znaczenie tego sanktuarium

\section{Z DZIEJÓW SANKTUARIUM}

Janusz Tyszkiewicz, wojewoda $\mathrm{i}$ generał ziem kijowskich, ufundował klasztor karmelitom bosym w Berdyczowie jako wotum wdzięczności dla Matki Bożej za uwolnienie go z niewoli tatarskiej ${ }^{\mathrm{l}}$. Definitorium Generalne w Rzymie, w dniu 5 XII 1628 r. przyjęło i zatwierdziło fundację w Berdyczowie, przeznaczając ją na seminarium misyjne wśród Kościoła ortodoksyjnego ${ }^{2}$. Po uzgodnieniu wszystkich warunków i otrzymaniu potrzebnych zezwoleń Janusz Tyszkiewicz 19 VII $1630 \mathrm{r}$. w Trybunale Lubelskim dokonał zapisu, mocą którego oddał swój zamek i plac w Berdyczowie na kościół i klasztor karmelitów bosych. $\mathrm{Na}$ utrzymanie zaś zakonników i klasztoru zapisał wieś Skrahlówkę oraz sumę 1800 zł rocznie ze swoich majątków. Fundację zatwierdził Bogusław Boxa Radoszewski, biskup kijowski, w Cudnowie 10 XI $1630 \mathrm{r}^{3}{ }^{3}$

W dniu 2 III 1634 r. biskup kijowski Andrzej Szołdrski poświęcił kamień węgielny pod budowę dolnego kościoła pod wezwaniem Niepokalanego Poczęcia NMP, św. Michała Archanioła, ss. Jana Chrzciciela i Jana Ew. W uroczystości wziął udział fundator Janusz Tyszkiewicz z żoną Jadwigą Bełzecka, kasztelanką halicka, w otoczeniu licznej rodziny. Budowa trwała 8 lat. Inauguracja życia za-

${ }^{1}$ Propugnaculum Regni Poloniae in summis Ukrainae finibus validissimum Beatissima Virgo Maria (...), Berdiczoviae /1760/, s. A; (O.Grzegorz od Ducha Św. - Jan S. P in o c c i), Ozdoba y obrona ukraińskich krajów przecudowna w berdyczowskim obrazie Marya (...), Berdyczów 1776, s. Ee 2 (Estr XXXI, 373).

${ }_{2}$ Acta Definitorii Generalis OCD Congregationis S. Eliae (16505-1658), ed. A., Fortes OCD, [w:] Monumenta Historica Carmeli Teresiani, Subsidia 3, Romae 1985, s. 160 (Acta Def. Gen.).

${ }^{3}$ Archiwum Prowincji Karmelitów Bosych w Czernej (APKB), AKB 2, Opis kościoła i klasztoru OO. Karmelitów Bosych w Berdyczowie dokonany w czasie wizytacji generalnej w 1786 r., k. 3; AKB 3, Wizyta kościoła i klasztoru berdyczowskiego XX. Karmelitów Bosych z rozkazu biskupa łuckiego i żytomierskiego (...) J. W. Michała Jana Piwnickiego za rok 1841 napisana, k. 12. 
konnego i poświęcenie dolnego kościoła odbyły się $22 \mathrm{VII} 1642 \mathrm{r}^{4} \mathrm{Z}$ tej okazji fundator ofiarował do nowego kościoła obraz Najśw. Maryi Panny, słynący od dawna łaskami w rodzinie Tyszkiewiczów ${ }^{5}$. Obraz ten otoczony wielkim kultem miejscowego ludu zajaśniał nowymi łaskami.

W latach 1739-1754 zbudowano górny kościół na fundamentach dolnego, typu bazylikowego na rzucie krzyża łacińskiego, z kopułą na skrzyżowaniu transeptu, według planów architekta Jana de Witte. Nową świątynię konsekrował 9 VI 1754 r. bp kijowski Kajetan Sołtyk ${ }^{6}$. Dla zabezpieczenia sanktuarium cały klasztor otoczono potężnym wałem z mostem zwodzonym, z bastionami w narożach muru obronnego, ze strzelnicami, uzbrojonymi 60 armatami. Pod rozkazami przeora utrzymywano stałą załogę w liczbie 120 żołnierzy, zdolną stawiać opór nieprzyjacielskim napadom. Twierdzę zwano „Fortecą Najśw. Maryi Panny”.

W XVIII i XIX w. klasztor berdyczowski stał się centrum nie tylko życia religijnego i maryjnego kultu na Ukrainie, ale też kulturalnego i dobroczynnego. Przez swoją drukarnię i szkoły położył wielkie zasługi na polu szerzenia oświaty i kultury ${ }^{7}$. Sanktuarium Matki Bożej stało się duchowa stolicą dla całej Ukrainy. Było świętym miejscem obecności Pana i przystanią pielgrzymującego i pokutującego ludu Bożego dla pojednania się z Bogiem, przez Maryję. W przywilejach i duchowych łaskach udzielonych przez Stolicę Apostolską dorównywało sanktuarium w Loreto.

Działalność klasztoru nie podobała się zaborczej Rosji. W roku 1866 nastapiła kasata klasztoru przez carski rząd, okupujący Polskę. Na krótki czas ponownie karmelici odzyskali sanktuarium od 1918 do 1926 r. Po śmierci o. Terezjusza Sztobryna komunistyczne władze Rosji przejęły klasztor na skarb państwa ${ }^{8}$. W górnym kościele urządzono muzeum a w dolnym - ateistyczne kino. W 1941 r., tuż przed niemiecką inwazją na Rosję, komuniści ograbili i spalili kościół oraz klasztor.

\section{OPIS ORYGINALNEGO OBRAZU}

Obraz Matki Bożej Berdyczowskiej z XVI w. należy do jednej z odmian typu hodegetrii. Jest wierną kopią obrazu Matki Bożej Śnieżnej zw. „Salus Populi Romani" z Bazyliki Santa Maria Maggiore w Rzymie. Obraz malowany techniką olejną na płótnie przymocowanym do cyprysowej deski o wymiarach: „wysoki na łokci dwa bez dwóch cali, szerokości 1 łokieć i ćwierć jedna", czyli ok. 120 x 75 $\mathrm{cm}$, w kształcie prostokąta.

Matka Boża jest przedstawiona frontalnie w 3/4 postaci z Dzieciątkiem Jezus na lewym ramieniu, pełna dostojeństwa, powabu i dobroci. Madonna prawą

${ }^{4}$ Tamże, k. 3.

${ }^{5}$ Propugnaculum Regni Poloniae..., s. A2.

${ }^{6}$ B. J. W a n at OCD, Zakon Karmelitów Bosych w Polsce, Klasztory karmelitów $i$ karmelitanek bosych 1605-1975, Kraków 1978, s. 381.

${ }^{7}$ Tamże, s. 382.

8 Tamże, s. 398-399.

${ }^{9} \mathrm{AKB} 2$, Opis kościoła i klasztoru..., k. 4 v. 
ręką podtrzymuje Dzieciątko w ten sposób, że obie dłonie są skrzyżowane, trzymając białą chustę w palcach lewej ręki oraz karmelitański szkaplerz na serdecznym i małym palcu prawej dłoni. Stanowi on karmelitańską adaptację Matki Bożej Szkaplerznej, prawdopodobnie z XVIII w. Głowy Madonny i Dzieciatka otaczają złote aureole - symbol świętości i szczęścia wiecznego. Tło obrazu w dolnej części ciemne, ku górze walorowo rozjaśnione z konturami anielskich główek, wynurzających się z obłoków.

Anonimowy autor obrazu berdyczowskiego nie trzymał się niewolniczo pierwowzoru. Malował w konwencji zachodniego malarstwa. Zachowujac typologiczną kompozycję i wymiary oryginału $(117 \times 79)^{10} \mathrm{w}$ dowolnej trawestacji $\mathrm{i}$ interpretacji zrezygnował $\mathrm{z}$ helenistycznej sztywności, linearyzmu, ze złotego tła i greckich liter, malując twarze współczesnych, żywych modeli, pełnych życia, piękna i ekspresji.

KULT MATKI BOSKIEJ BERDYCZOWSKIEJ

I WAŻNIEJSZE ŁASKI

W poczatkowym okresie rozwoju kultu Matki Bożej Berdyczowskiej ważnym momentem było cudowne uzdrowienie samego biskupa kijowskiego Stanisława Zaręby z Kalinowy. Ordynariusz, po zapoznaniu sie z dokumentacja uzyskanych łask i cudów przez pośrednictwo Matki Bożej, aktem władzy biskupiej w dniu 23 maja 1647 r. uznał i publicznie ogłosił za cudowny obraz Matki Bożej Berdyczowskiej ${ }^{11}$. Od tego stwierdzenia wierni jeszcze bardziej garnęli się we wszystkich potrzebach do Maryi. Przybywali do Jej sanktuarium indywidualnie lub w zorganizowanych pielgrzymkach. Z XVII w. mamy zaprotokołowanych 77 uzyskanych łask Matki Bożej ${ }^{12}$. Z analizy protokołów wynika, że przybywali do Berdyczowa ludzie wszystkich stanów społecznych.. Z rodzin magnackich wymienieni są Tyszkiewiczowie, Jelcowie, Kazanowscy, Kalinowscy, Lubomirscy, Potoccy, Chojeccy itd. ${ }^{13}$

W latach od 1721 do 1732 zaprotokołowano 23 łaski, a w czasie pobytu obrazu u SS. Karmelitanek Bosych w Lublinie (1732-1736) - 4 uzdrowienia. Od 1736 do 1756 roku zarejestrowano 87 łask i cudów, czyli razem 114 łask do czasu koronacji obrazu. $Z$ analizy opisu łask wynika, że obdarowani łaskami należeli do Kościoła Rzymskokatolickiego, Grekokatolickiego i Prawosławnego.

W dniu 4 maja 1752 r. komisja teologiczna, powołana przez biskupa kijowskiego Samuela Ozgę, rozpoczęła prace badawcze nad autentycznością łask i przesłuchiwaniem świadków. W wyniku badan przeprowadzonych przez biskupią ko-

${ }^{10}$ Pietro A m a t o, De vera effigie Mariae - Antiche Icone Romane, Roma 1988, s. 52-60.

$"$ Propugnaculum Regni Poloniae, s. 42.

${ }^{12}$ Ozdoba y obrona, s. Mn - Oo; W. N o w a k o w s k i, O cudownym obrazie Najśw. Maryi P. Berdyczowskiej, Kraków 1987, s. 14; D. B a c z k o w s k i, Historia pokarmelitańskiego kościoła i klasztoru w Berdyczowie, Warszawa 1912, s. 14.

${ }^{13}$ Tamże. 
misję do roku 1756 urzędowo stwierdzono 253 łaski, w tym 14 wskrzeszeń umarłych, 10 uzdrowień $\mathrm{z}$ rozmaitych kalectw, 19 odzyskań wzroku, 14 uzdrowień konających, 112 nagłych uleczeń $z$ ciężkich chorób ${ }^{14}$. Pozostałe łaski dotyczyły ratunku w różnych zagrożeniach od szatana, złych ludzi, od ognia, wody i zarazy oraz odzyskania utraconego mienia. Komisja potwierdziła autentyczność łask przebadanych według ówczesnych kryteriów Kościoła oraz potwierdziła wcześniejszą decyzję biskupa Stanisława Zaręby o cudowności berdyczowskiego obrazu.

Rozgłos o łaskawości i Miłosierdziu Matki Bożej w Berdyczowie gromadził ludzi na nabożeństwa ze wszystkich stron Ukrainy i terenów Rosji. Karmelici rozwijali kult Matki Bożej przez uroczyste nabożeństwa we wszystkie święta maryjne, nowenny, oktawy z procesjami. Centralnym odpustem była uroczystość Matki Bożej Szkaplerznej (16 lipca), Matki Bożej Śnieżnej (5 sierpnia) i Niepokalanego Poczęcia ( 8 grudnia). Układ nabożeństw w sanktuarium, był bardzo bogaty ${ }^{15}$. Codziennie o godz. $5^{30}$ dzwony wzywały wszystkich na modlitwę a następnie trębacze grali pieśni maryjne $\mathrm{z}$ ganku fasady kościoła. W niedzielę $\mathrm{i}$ święta o godz. $6^{30}$ na odgłos dzwonu na Anioł Pański rozpoczynała się liturgia Mszy św. zwanej prymarią, w czasie której chór kościelny śpiewał pieśni. O godz. $7^{30}$ Msza św. zwana „ruską”, czyli w rycie bizantyjskim z udziałem śpiewaków nazwanych diaczkami. Po niej były grane i śpiewane Godzinki o Niepokalanym Poczęciu NMP. O godz. $9^{00}$ była Msza św. wotywna o NMP, śpiewana i grana przez kapelę. O godz. $11^{00}$ odprawiano uroczystą sumę z udziałem zespołu kapeli klasztornej. Po sumie była grana przez kapelę i śpiewana przez wiernych litania do NMP. Po południu o godz. $16^{00}$ były nieszpory, a po ich zakończeniu zakonnicy w białych płaszczach śpiewali przed ołtarzem Matki Bożej uroczystą antyfonę „Sub Tuum praesidium”, po której następowało zasłonięcie cudownego wizerunku.

W dni powszednie w ciagu całego roku o godz. $6^{00}$ odprawiano Mszę św. śpiewaną i graną przez kapelę za zmarlych. Po niej były Godzinki o Niepokalanym Poczęciu NMP. O godz. $7^{00}$ była Msza św. wotywna o NMP, śpiewana i grana przez kapelę. O godz. $9^{00}$ codziennie odprawiano Mszę św. tzw. "ruską", czyli w obrządku bizantyjskim dla unitów (prawosławnych). O godz. $10^{00}$ była grana i śpiewana przez zespół instrumentalno-wokalny litania do NMP. Po południu o godz. $15^{00}$ była grana przez kapelę i śpiewana przez pielgrzymów litania do NMP. Na zakończenie nabożeństwa, przed zasłonięciem obrazu, zakonnicy w białych płaszczach śpiewali antyfonę maryjną „Sub Tuum praesidium", a w soboty "Salve Regina".

Drukarnia „Fortecy Najśw. Maryi Panny” zaspokajała potrzeby pielgrzymów w religijną literaturę, podręczniki do nabożeństw., kalendarze w języku polskim i ruskim oraz graficzne reprodukcje cudownego wizerunku zabierane do domów i czczone na wzór ikony ${ }^{16}$.

${ }^{14}$ Tamże, s. Ddd.

${ }^{15}$ Porządek nabożeństw w sanktuarium Matki Bożej Berdyczowskiej pochodzi z księgi wizytacji generalnej kościoła i klasztoru berdyczowskiego z 1786 r. - AKB2, Opis kościoła i klasztoru, k. 19-20; J. B. W a n at OCD, Zakon Karmelitów Bosych w Polsce..., s. 383.

${ }^{16}$ Wykaz druków berdyczowskich sporządził Jan Marek Giżycki. - APKB w Czernej, rkps 36, Berdyczów - Klasztor OO. Karmelitów Bosych, k. 150-212. 
Po stwierdzeniu cudowności obrazu i udowodnieniu jej autentycznymi łaskami i cudami przez biskupią komisję, na prośbę karmelitów bosych w Berdyczowie, duchowieństwa i licznych pielgrzymów, ks. bp Kajetan Sołtyk zwrócił się do Stanów Rzeczypospolitej na Sejmie w Grodnie 1752 r. o poparcie tej prośby do Stolicy Apostolskiej o ukoronowanie obrazu papieskimi koronami. Sejm pozytywnie ustosunkował się do tej prośby i propozycji. Król polski August III i prymas abp gnieźnieński Adam Komorowski napisali prośby w imieniu Sejmu do Ojca św. Benedykta XIV. Podobne pisma skierowali również wyżsi urzędnicy województwa kijowskiego z rycerstwem całej Ukrainy. Ci ostatni prosili nadto Ojca św. o przysłanie relikwii św. męczennika żołnierza dla obrony przedmurza chrześcijańskiego. Papieź nie tylko wyraził zgodę na koronację obrazu, ale przysłał złote, ozdobione szmaragdami, przez niego poświęcone korony wraz z koronacyjnym dekretem Kapituły Watykańskiej z dnia 28 stycznia $1753 \mathrm{r}^{17}{ }^{17}$ Razem z koronami dla klasztoru w Berdyczowie Papież przysłał relikwie ciała św. Teodora, żołnierza i męczennika, oraz część choragwi św. Jerzego dla umocnienia i obrony chrześcijańskich wartości i katolickich więzi z Rzymem na tym terenie.

Koronację wizerunku Matki Bożej odłożono do czasu ukończenia budowy i wystroju górnego kościoła, przeznaczonego na właściwe sanktuarium. Odbyła się ona 16 lipca $1756 \mathrm{r}$. z królewskim przepychem i rozbudowanym ceremoniałem w duchu baroku. Dokonano jej poza miastem na obszernym placu, gdzie wzniesiono drewnianą kaplicę z 11 ołtarzami, w której mogło się pomieścić 20 000 osób. Cały kościół i kaplicę udekorowano sztukateria, rzeźbami, obrazami przedstawiającymi cuda Matki Bożej Berdyczowskiej, symbolami maryjnymi. portretami panujących i fundatorów. Aleję zaś od kościoła do koronacyjnego ołtarza przyozdobiono lampionami na cokołach i ośmioma bramami triumfalnymi w barokowej architekturze, rzeźbami i malarskimi kompozycjami na płótnie, popiersiami oraz symbolami i panopliami ${ }^{18}$.

Koronacji przewodniczył ks. bp Kajetan Sołtyk z Kijowa. Uczestniczyli w niej: bp Włodkowicz, koadiutor metropolii ruskiej obrzadku grecko-unickiego z licznym duchowieństwem, Kapituła Kijowska z duchowieństwem obrządku rzymsko-katolickiego, przedstawiciele różnych zakonów, bractw, stowarzyszen, wojsko w liczbie 6000 husarskich i pancernych choragwi pod dowództwem księcia Antoniego Lubomirskiego, miecznika wielkiego koronnego, i ok. 50000 wiernych z różnych stron Polski i Litwy. O godz. $9^{00}$, po przeniesieniu z kościoła papieskich koron, protonotariusz apostolski odczytał dekret koronacyjny oraz ogłosił możliwość uzyskania odpustu zupełnego pod zwykłymi warunkami. Następnie koronator nałożył korony na skronie Dzieciątka Jezus i Maryi przy dźwiękach trąb i kotłów, huku dział. Po nałożeniu koron rozdawano na pamiątke złote, srebrne i mosiężne

${ }^{17}$ B. J. W a n a OCD, Zakon Karmelitów Bosych w Polsce, s. 401; APKB w Czernej, Dyp. 15. Druk. Ozdoba y obrona..., s. Pff.

${ }^{18}$ Dekoracje szopy, kościoła i triumfalnych bram utrwalone zostały w miedziorytowej grafice, wykonanej przez Teodora Rakowieckiego i Teofila Trockiewicza. - Ozdoba y obrona..., s. Eee 2, Mmm - Yyy 2. 
medale, obdarzone odpustami na godzinę śmierci. Po Mszy św. pontyfikalnej przeniesiono w procesji obraz do kościoła. Przez całą oktawę odprawiane były uroczyste nabożeństwa $\mathrm{z}$ kazaniami na sumie i nieszporach najsławniejszych kaznodziejów, oraz odbywały się filozoficzne i teologiczne dysputy ${ }^{19}$.

W 1820 r. złote korony papieża Benedykta XIV zostały skradzione wraz $\mathrm{z}$ innymi rzeczami kościoła. Po ich odnalezieniu ponownie skradziono je w $1831 \mathrm{r}$. $\mathrm{Na}$ ich miejsce Józef Zdziechowski, sędzia powiatu lipowieckiego sprawił nowe korony, które poświęcił i założył bp Michał Piwnicki w $1844 \mathrm{r}$. Kiedy i te zostały skradzione, wówczas Ojciec św. Pius IX ufundował i przysłał nowe korony z poleceniem dokonania powtómej koronacji. Dokonał jej prawie w 100-lecie pierwszej koronacji bp Kasper Borowski 6 czerwca $1854 \mathrm{r}^{20}$ Uroczystość zgromadziła ok. 100000 wiernych Kościoła katolickiego i prawosławnego. Kazanie wygłosił słynny mówca ks. Lucjan Godlewski ${ }^{21}$. Korony przyozdabiały obraz wraz z kosztownymi sukienkami aż do wojny bolszewickiej w $1920 \mathrm{r}$. Komunizm zniszczył całkowicie sanktuarium Matki Bożej Berdyczowskiej. Pocięto i przetopiono srebrną ramę obrazu $(75 \mathrm{~kg})$ i rozkradziono kilka tysięcy wotów z wielkiego ołtarza. Zginęły bogate szaty i sam obraz Matki Bożej oraz złote i srebrne argenteria zakrystii. Spalone zostały wszystkie ołtarze i cały wystrój wnętrza kościoła. Stłuczono aż do cegły wszystkie sztukaterie i artystyczną polichromie świątyni. Celowo zacierano i niszczono wszystkie ślady kultu w ateistycznym państwie.

\section{NOWY OBRAZ MATKI BOŻEJ BERDYCZOWSKIEJ}

Po daremnych poszukiwaniach oryginalnego wizerunku Matki Bożej Berdyczowskiej na terenach Ukrainy i Polski, o. Prowincjał Karmelitów Bosych prowincji Ducha Świętego postanowił w jesieni 1990 roku zlecić namalowanie nowego obrazu, przeznaczonego do kultu. Zlecenie przyjęła artystka malarka i konserwatorka Bożena Mucha Sowińska w Krakowie-Nowej Hucie.

Wykonanie nowego obrazu - wiernej kopii Matki Bożej Berdyczowskiej związane było z dużymi trudnościami. Pośród licznych reprodukcji i zebranej ikonografii brakowało kolorowego zdjęcia oryginału. Wszystkie przekazy ukazywały Matkę Bożą Berdyczowską ubraną w haftowaną suknię z koroną na głowie. Sukienka zaś przysłaniała kolorystyke i kompozycję samego obrazu. Jedynym i bardzo cennym przekazem stał się dokładny opis kompozycyjny i kolory-

${ }^{19}$ Pełną dokumentacje uroczystej koronacji z przemowami i kazaniami opracował i wydał w Drukarni Fortecy NMP o. Grzegorz od Ducha Św. (Jan Sylwester Pinocci) OCD (mylnie nazwany przez Estreichera Trześniewskim, Estr. XXXI. 373) [w:] Ozdoba y obrona..., Berdyczów 1767. Zob. też A. Gro z a, Wiadomość o cudownym obrazie Najśw. Maryi Panny Berdyczowskiej, [w:] „Pamiętnik Religijno-moralny", Warszawa 1852, t. 32, s. 57; X. W. N o w a k o w s ki, O cudownym obrazie, s. 15-23.

${ }^{20}$ W. N owak ow ski, op. cit., s. 29; A. Fridrich SJ, Historye cudownych obrazów Najświętszej Maryi Panny w Polsce, t. 4, Kraków 1911, s, 268.

${ }^{21}$ Kazanie miane R.P. 1854 w czasie powtórnej koronacji cudownego obrazu N.P. Maryi Berdyczowskiej przez ks. Lucyana Godlewskiego, Lwów 1876. 
styczny obrazu. wykonany przez o. Bronisława Jarosińskiego ${ }^{22}$, kustosza sanktuarium Matki Bożej w Berdyczowie w latach 1921-1925. Po wyjęciu łaskami słynącego obrazu $\mathrm{z}$ ołtarza $\mathrm{i}$ zdjęciu sukienki oraz korony dokonał on jego oczyszczenia i zabezpieczenia. Przy tej okazji dokonał również szczegółowego opisu kolorystycznego wizerunku, według którego nowy obraz został wykonany.

Nowy obraz Madonny został namalowany w 1991 r. na jednolitej płycie z wodoodpornej prasowanej sklejki o wymiarach 143 x $93 \mathrm{~cm}$ w kształcie prostokąta. Na płyte naklejone zostało płótno podobrazia. Po zagruntowaniu płótna wykonana została techniką olejno-żywiczną kompozycja Madonny w typie hodegetrii, na wzór Matki Bożej Śnieżnej. Opis formalno-kolorystyczny kompozycji jak w oryginale. Nowy obraz różni się od swego wzoru strukturą materialna, wymiarami i skalą wartości zabytku XVI wieku. Artystka nie trzymała się niewolniczo oryginału. Dokonała udanej trawestacji tła obrazu, wzbogacajac je figuralnymi kompozycjami aniołów wokół głowy Madonny i Dzieciątka Jezus oraz umieszczając w zwieńczeniu oko Opatrzności Bożej w trójkącie. Ten symbol Trójcy Świętej przypomina określenie św. Alfonsa Liguoriego, że „Maryja jest arcydziełem Trójcy Świętej" oraz Jej dziełem jest szczególna łaska i przywilej Macierzyństwa Bożego NMP.

\section{KORONACJA NOWEGO OBRAZU}

Przygotowaniem wiernych do koronacji była dziewięcio-tygodniowa nowenna. W każdą niedzielę jeden z Biskupów Ukrainy celebrował Mszę św. i głosił kazanie o Matce Bożej. Nowennę rozpoczał ks. abp Marian Jaworski, Metropolita Lwowa i Przewodniczący Konferencji Episkopatu Ukrainy. W ostatni dzień nowenny /18 VII/ przewodniczył i homilię wygłosił w koncelebrze biskupów i licznych kapłanów o. Flavio Caloi, wikariusz generalny i delegat Generała Zakonu z Rzymu. Liturgia odbyła się przy ołtarzu polowym na placu przed murami fortecznymi klasztoru. Cały plac wypełniony był pielgrzymami, przybyłymi na uroczystość z całej Ukrainy, z Polski, Słowacji, Czech, Chorwacji, Niemiec, Białorusi, Rosji, Litwy i Łotwy. Pielgrzymi czuwali całą noc na modlitwie.

W niedziele 19 lipca 1998 r. o godz. 10.30 wyruszyła z kościoła procesja z obrazem Matki Bożej Szkaplerznej na plac koronacyjny, przy dźwięku pieśni miejscowego chóru młodzieży. Po rozpoczęciu liturgii Eucharystycznej przez ks. bpa Jana Purwińskiego, ordynariusza Diecezji Żytomierskiej, o. Piotr Hewelt delegat o. Prowincjała na Ukrainę, powitał w imieniu Karmelu i wiernych wszystkich przybyłych gości z Biskupem Koronatorem na czele. W uroczystości wzięli udział członkowie Episkopatu Ukrainy: bp Jan Olszański - ordynariusz kamieniecko-podolski, bp Markijan Trofimiak - ordynariusz łucki, bp Stanisław Padewski biskup pomocniczy kamieniecko-podolski, bp Leon Dubrawski - biskup pomocniczy kamieniecko-podolski, bp Stanislaw Szyrokoradiuk - biskup pomocniczy ży-

${ }^{22}$ O. B. J a r o s i ń s k i OCD, Matka Boska Berdyczowska - krótki opis cudownego obrazu, „Glos Karmelu”, 8:1928, s. 231-233. 
tomierski. Biskup z Niemiec; delegat generała Karmelitów Bosych z Rzymu o. Flavio Caloi, o. Szczepan Praśkiewicz - konsultor Kongregacji d/s Świętych, o. Wiesław Kiwior - prowincjał Prowincji Krakowskiej, o. Benignus Wanat - wikariusz prowincjalny. Ponadto w koncelebrze wzięło udział ok. 90 kapłanów diecezjalnych i zakonnych. Gościem honorowym był ks. Proboszcz parafii św. Mikołaja, Kościoła Prawosławnego. Na placu zgromadziło się ok. 15000 wiernych, kilkudziesięciu kapłanów-spowiedników, liczni klerycy i bracia zakonni a także ok. 100 sióstr zakonnych. W pierwszym sektorze przed ołtarzem koronacyjnym zajęło miejsca kilkanaście delegacji Ambasad i Konsulatów na Ukrainie, przedstawiciele Parlamentu Ukrainy, administracyjne Władze Kijowa, Żytomierza i Berdyczowa. Porządku na placu strzegła milicja i wojsko.

Po odczytaniu Ewangelii w kilku językach bp pomocniczy Żytomierza odczytał Apostolskie Brewe Jana Pawła II zezwalające na koronację nowego obrazu Matki Bożej Berdyczowskiej. Z kolei Biskup Koronator poświęcił nowe korony i przy dźwiękach fanfar nałożył je na skronie Dzieciątka Jezus i Matki Bożej. Wierni na placu pełni wzruszenia spontanicznie wyrazili swoją radość oklaskami. Po tym akcie o. Benedykt Krok - kustosz sanktuarium złożył ślubowanie, że dołoży wszystkich starań, aby Matka Boża ponownie na tym miejscu była kochana, czczona i naśladowana. Zawierzył Matce i Królowej Ukrainy cały naród, wszystkie miasta i wioski, cały Kościół i wszystkie instytucje państwowe. Radości i oklaskom nie było końca. Bp Jan Purwiński - koronator obrazu wygłosił płomienne i bardzo odważne kazanie w języku ukraińskim i polskim. W czasie Mszy św. śpiewano pieśni maryjne w języku polskim, ukraińskim i rosyjskim. Rzesze ludzi przystapiło do spowiedzi, Komunii św. i przyjęło Szkaplerz Karmelitański. Przebieg całej uroczystości dokumentowały liczne kamery telewizji i dziennikarze.

Koronacja obrazu Matki Bożej Szkaplerznej w Berdyczowie była pierwszą i największą uroczystością religijną w XX wieku na Ukrainie, a szczególnie po rewolucji październikowej. Klasztor Karmelitów Bosych w Berdyczowie ponownie odzyskał rangę narodowego Sanktuarium Matki Bożej na Ukrainie. 


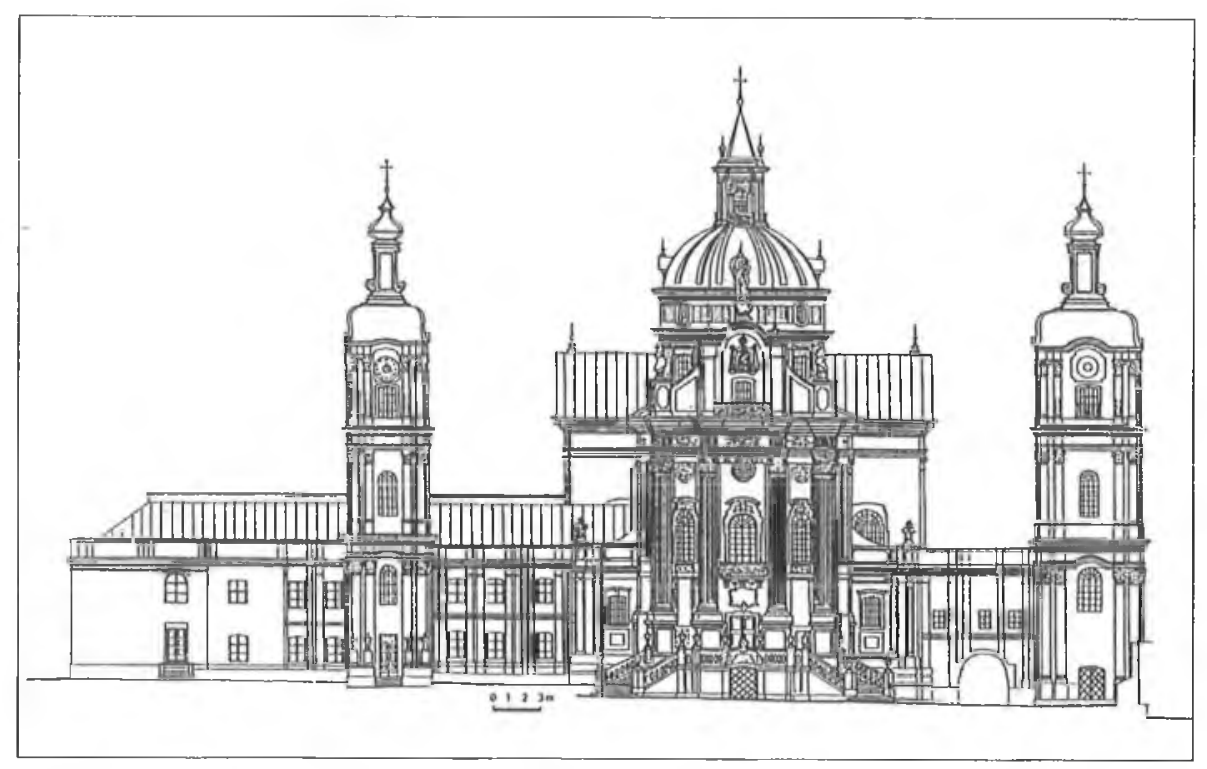

1. Berdyczów. Fasada kościoła i klasztoru. Pomiary: B. T. Cijauk, B. Korniejewa (1993).

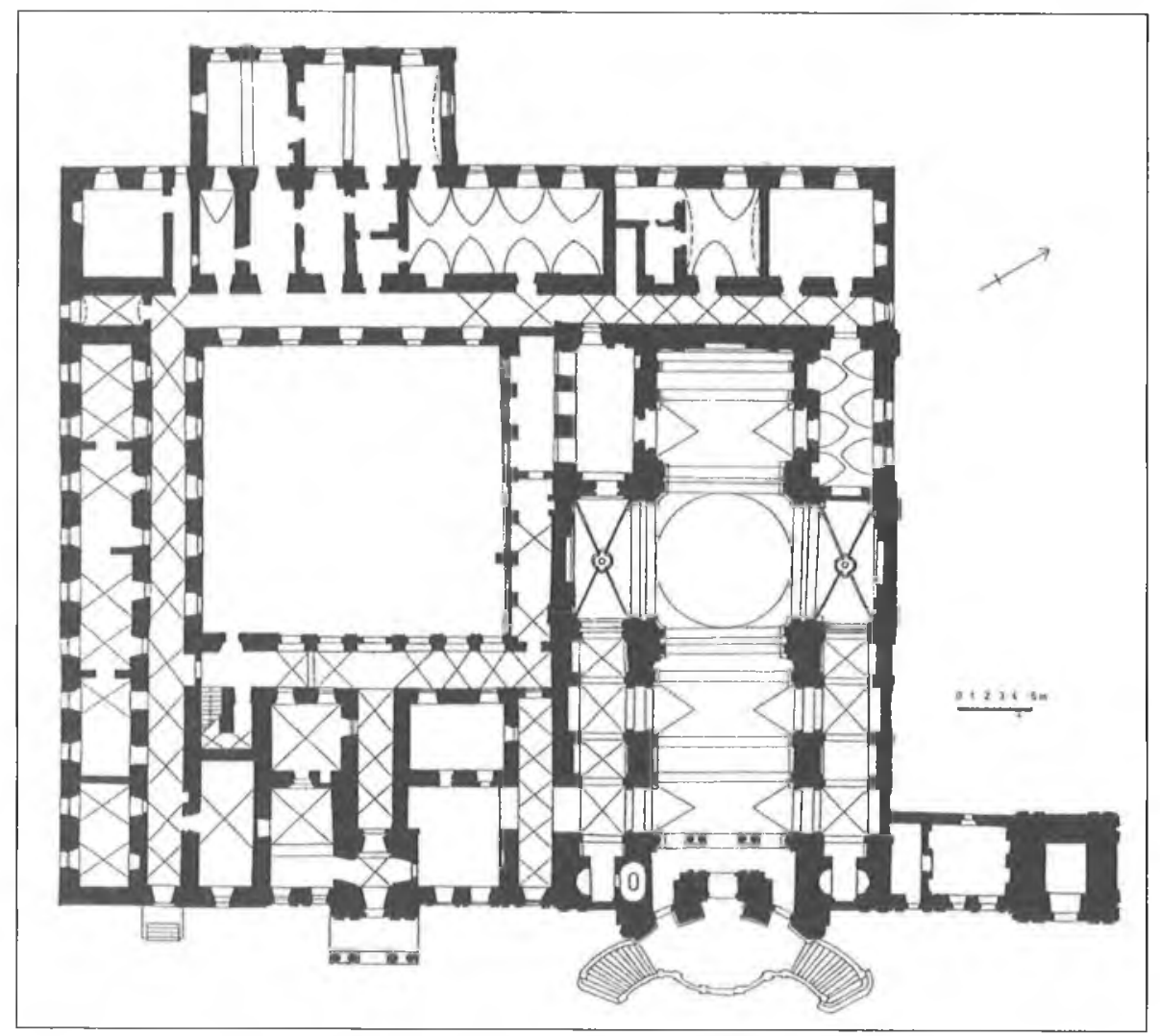

2. Rzut przyziemia klasztoru i kościoła w Berdyczowie. 


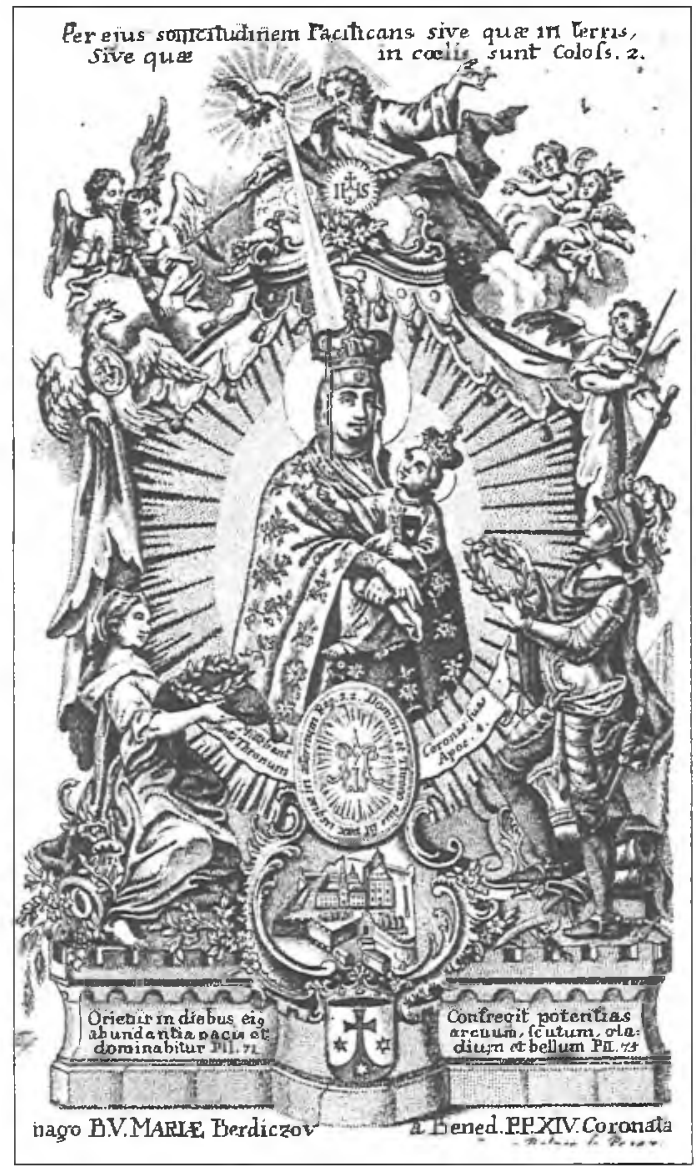

3. Obraz Matki Bożej Berdyczowskiej. Miedzioryt Jana Balcera z Pragi (2 poł. XVIII w.). 


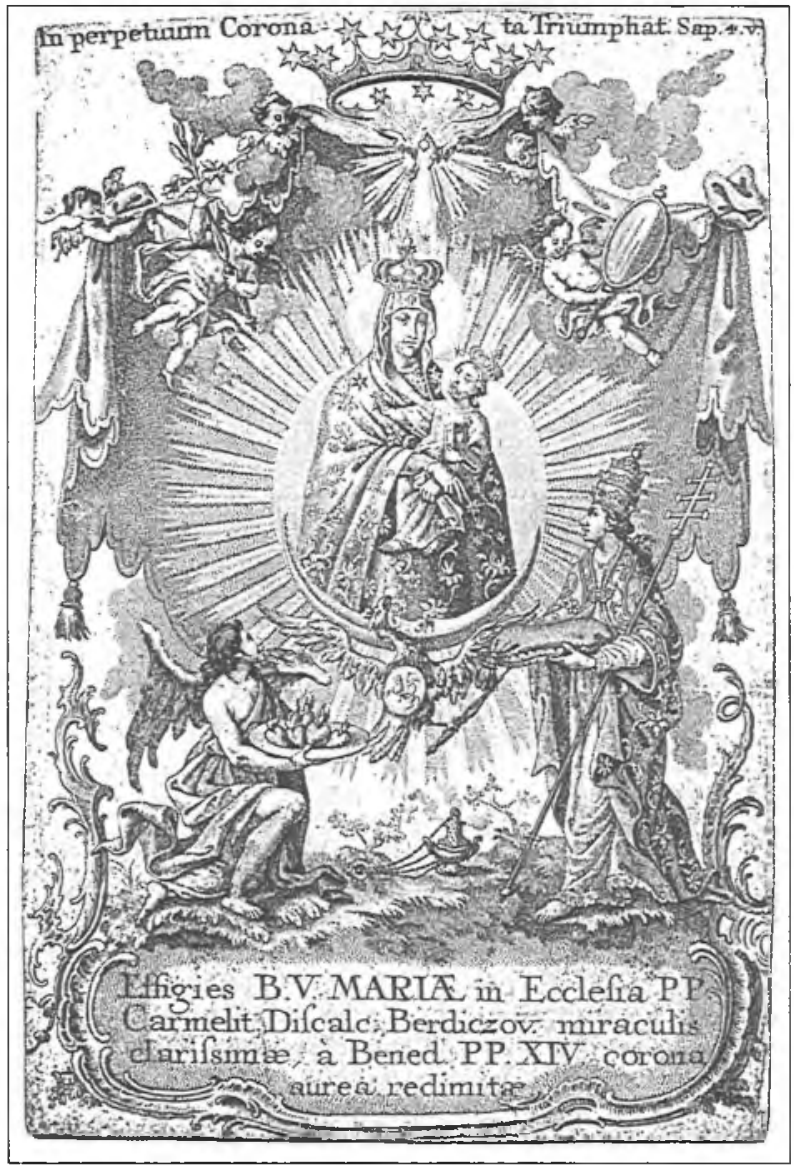

4. Obraz Matki Bożej Berdyczowskiej. Miedzioryt Ignacego Verhelsta (2 poł. XVIII w.). 


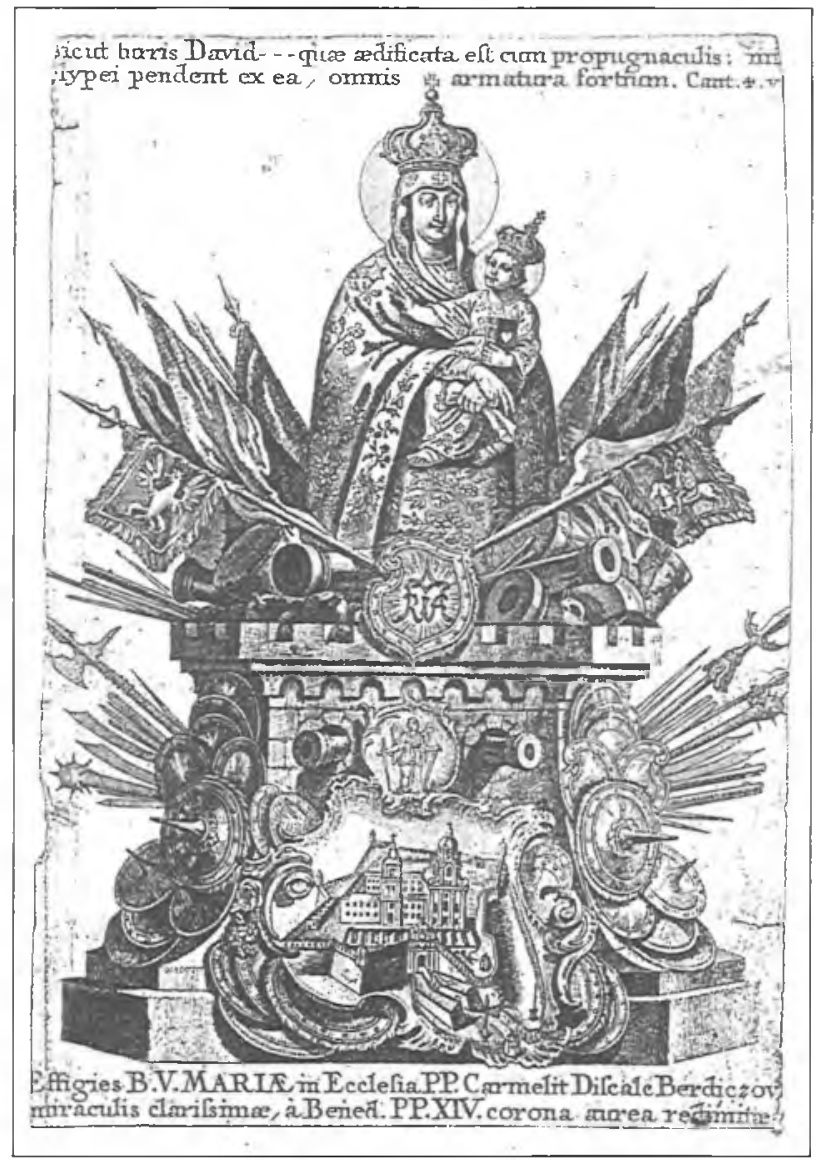

5. Obraz Matki Bożej otoczony armaturą z widokiem klasztoru. Miedzioryt: Göz senior (Gottfied Berhard) et junior (Franz Regis z 2 poł. XVIII w.). 


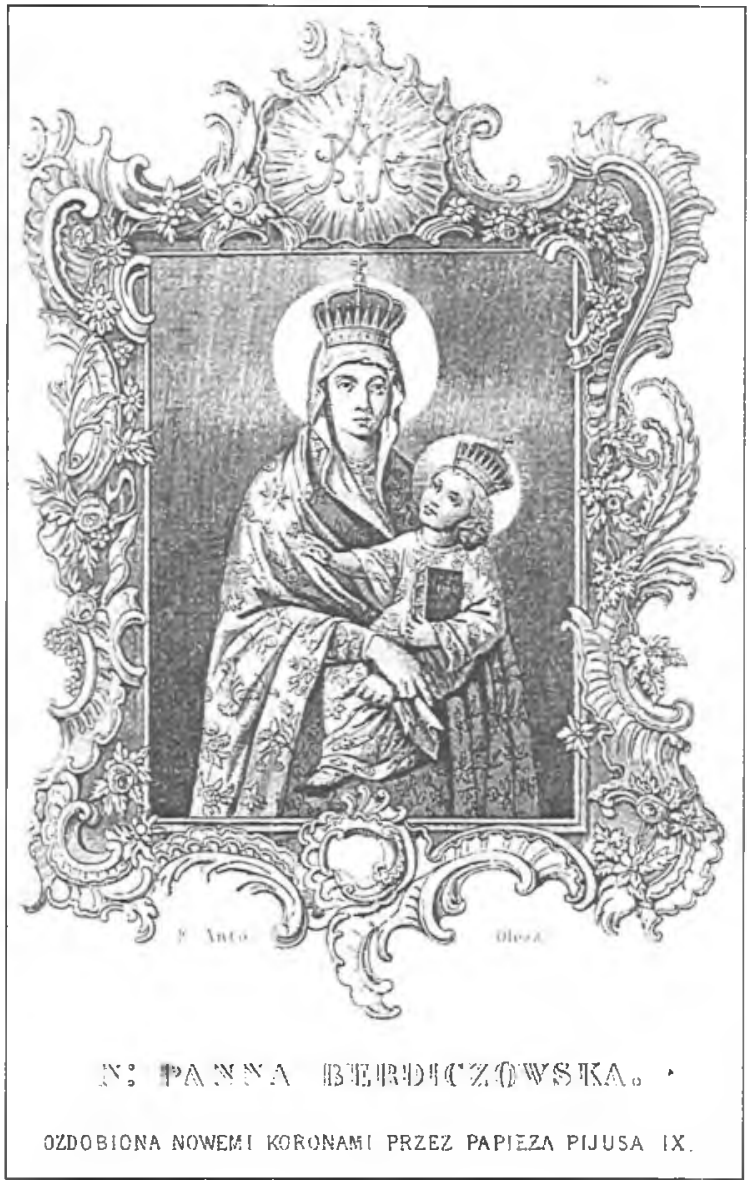

6. Obraz Matki Bożej Szkaplerznej. Staloryt Antoniego Oleszczyńskiego z XIX w. 


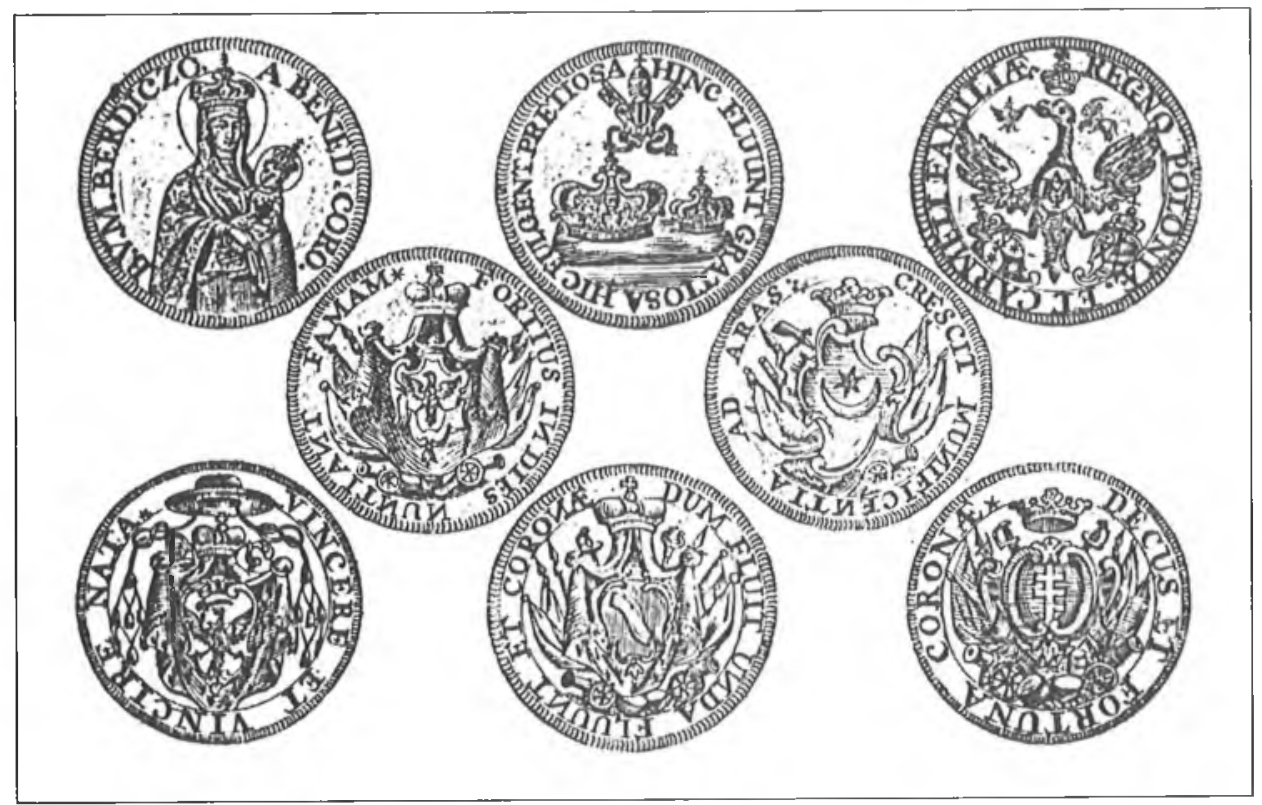

7. Medale wybite na koronację obrazu. Miedzioryty Teodora Rakowieckiego z XVIII w.

8. Nowy obraz Matki Bożej ukoronowany w $1998 \mathrm{r}$.

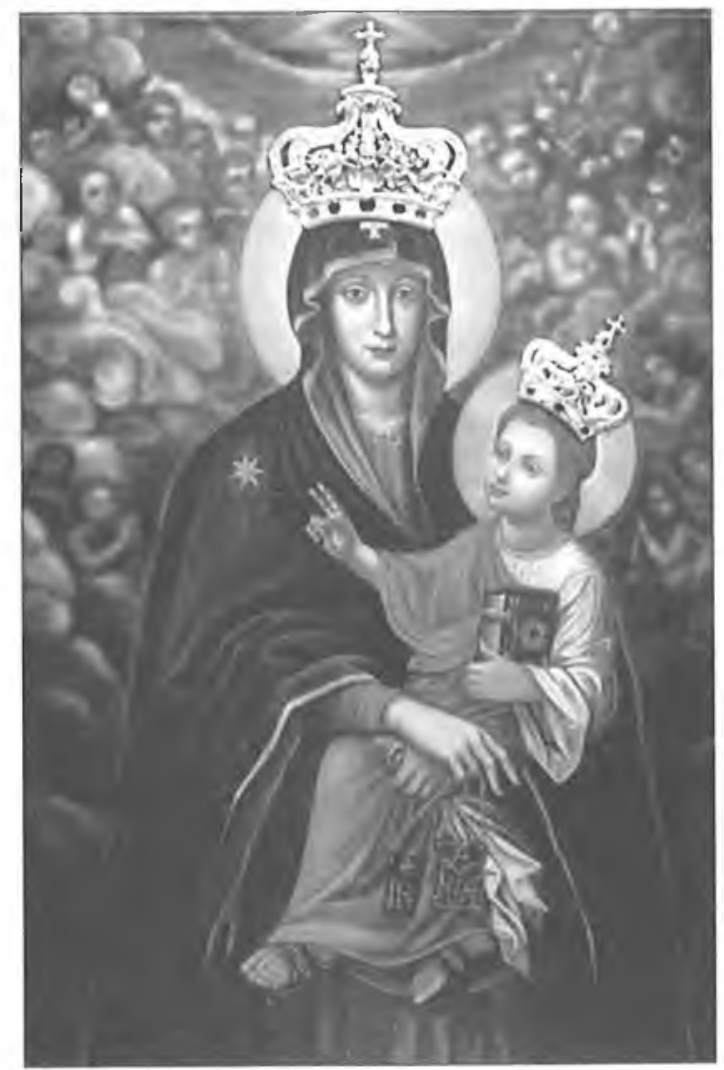




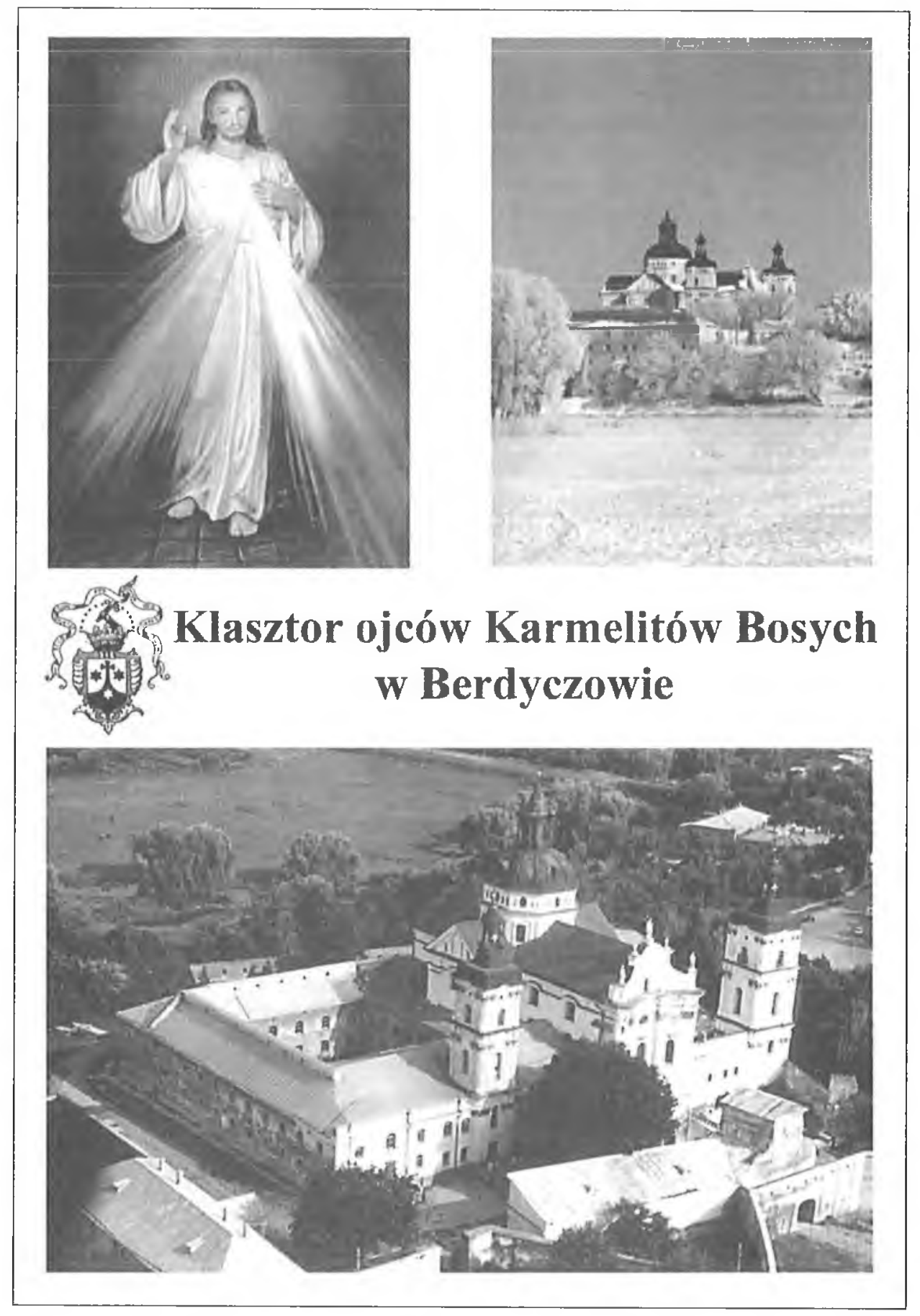

9. Klasztor Karmelitów Bosych w Berdyczowie. 